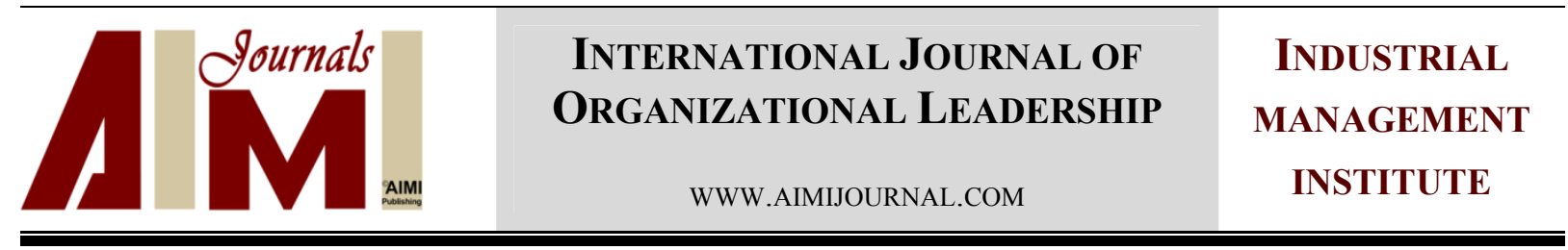

\title{
A Critical Review of Implicit Leadership Theory on the Validity of Organizational Actor-National Culture Fitness
}

\author{
Alperen Öztürk ${ }^{*}$, M. Abdülkadir Varoğlu ${ }^{2}$ Demet Varoğlu ${ }^{3}$ \\ ${ }^{1,2}$ Baskent University, Faculty of Economics and Administrative Sciences \\ ${ }^{3}$ TOBB University of Economics and Technology, Faculty of Economics and Administrative Sciences
}

\begin{abstract}
Keywords:

Leadership, National

Culture, Implicit

Leadership Theory

According to implicit leadership literature, actor-national culture fitness is a necessity to be labeled as a leader. However, studies which focus on implicit leadership theory and national culture have some contradictory findings. A systematic review of these studies reveals that participants could score high on opposite implicit leadership values and a sufficient theoretical explanation for these surprising results have not been given so far. This paper

\section{Received}

02 December 2016

Received in revised form

01 November 2017

Accepted

24 November 2017

Correspondence: argues that showing full harmony with the cultural expectations of followers is not a necessity to be seen as a leader. Actors who can fill the cultural gap with their different cultural values can also be labeled as leaders. This paper contends that organizational actors with cultural values differing from those of the followers with certain cultural orientations are more likely to be labeled as leaders. People from individualistic societies may be more prone to label 'team oriented leadership' dimension as their outstanding leadership prototype whereas people from masculine societies may show 'humane oriented leadership' as their outstanding leadership prototype.
\end{abstract}

alperen@baskent.edu.tr

C)AIMI Journals

This study reevaluates that the notion of "implicit leadership prototype-national culture fitness must be ensured for becoming a leader on followers' minds" (Bass, 1997; Byrne \& Bradley 2007; Dorfman et al., 2012; Javidan, Bullough, \& Dibble, 2006; Pasa, Kabasakal, \& Bodur, 2001; Ronen \&Shenkar, 1985; Shim \& Steers, 2012; Smith et al., 1989). Culture studies generally focus on a vast majority of population for determining dominant cultural values. However, focusing only on majority may cause some problems. Every single individual may not adopt the same 
cultural values like the rest of the majority. People who live in same country may hold very different or opposing cultural values. These different people may find some opportunities to turn into leaders through the cultural constraints (Hofstede, 1993). Culture directs people to favor some specific organizing and working models over others in organizations (team work vs individual work). Turbulent and uncertain work conditions may cause unusual problems. Different viewpoints may be needed for finding solutions to this kind of problems. If culturally different actors solve problems with their social skills, they may be assumed as leaders by employees. On the other hand, leadership recognition and acceptance process may not have the same momentum among different cultures. Some cultures may be more open to distinctness and they may approve leadership of different actors more quickly. Employees who embrace one pole of culture may be in need of a different kind of leadership. Highly individualistic people may want to work with team oriented leaders. Highly masculine oriented people may prefer humane leadership in organizations.

\section{Leadership}

Even though leadership literature is getting richer every day, in this regard, it is still hard to define leadership or determine the main characteristics of leaders. Some researchers treated leadership as a context dependent phenomenon (Smircich \& Morgan, 1982; Summerfield, 2014). According to Smircich and Morgan (1982) leadership is embedded in the environment and beholder's observations convert an actor to a leader. Kotter (2001) argues that the main job of a leader is to manage and to execute organizational change. Classic leadership definitions involve a particular environment, extraordinary leader behaviors, goals, and leader-follower interactions (Day \& Antonakis, 2012; Horner, 1997). However, Day and Antonakis (2012) criticize these definitions for being too much leader-centric. Instead of trying to define leadership, reviewing leadership literature and examining evolution of leadership paradigms may be more helpful for a better understanding of this concept.

Leadership literature has divergent and contesting paradigms (Day \& Antonakis, 2012). These paradigms are trait-personality, behavioral, contingency (situational), interpersonal leader-member relations, transformational-transactional, neo charismatic, information processing (implicit leadership), culture dependent, biological-evolutionary, and globally thinking leadership theories (Day et al., 2014; Day \& Antonakis, 2012; Dinh et al., 2014; Horner, 1997; House \& Aditya; 1997; Javidan et al., 2016; Mathews, 2016; Mortensen et al., 2014). The main purpose of the first leadership paradigm, trait school of leadership (Day \& Antonakis, 2012; Dinh et al., 2014; House \& Aditya 1997; Mortensen et al., 2014), is to specify the great leaders, then, deeply examine these leaders and discover their great traits (Horner, 1997).Researches conducted within the trait school of leadership have failed to identify universal leadership characteristics which would be valid in any cultural context (Northouse, 2010).Nowadays, the trait paradigm seems to be obsolete, even though it is not completely abandoned.

Second important leadership paradigm is the behavioral leadership theory (Derue, Nahrgang, Wellman, \& Humphrey, 2011). In this framework, leadership can be defined as the actor's functional behavior which effects all others positively in an organization (Bowers \& Seashore, 1966). Generally, behavioral leadership theory tries to discover and classify actions which leaders use for effectiveness (Derue et al., 2011). The third leadership school is contingency 
theory (Day \& Antonakis, 2012; Dinh et al, 2014; House \& Aditya, 1997). With contingency theory, researchers have shifted their focus from actor to situation (Hill, 1969; Justis, 1975). Contingency theory is about matching leadership styles with contingent factors (Campbell, 1968). Most known forms of contingency theory can be listed as path-goal theory (House, 1971), situational leadership theory and life cycle theory (Dinh et al., 2014; House \& Aditya, 1997). Even though theories like situational leadership brought new insights to leadership studies, they cannot completely explain the leadership concept. Graeff (1983) heavily criticized situational leadership theory for having internal consistency problems and a lack of theoretical explanations. Vecchio (1987) asserted that situational leadership theory only works on certain types of employees. Blank, Weitzel, and Green (1990) also could not find empirical support for situational leadership theory's prescriptions. After the disputes concerning contingency school, more social and relational theories have emerged in the field of leadership. Social and relational leadership theories can be thought as the fourth paradigm of leadership. One of the most prominent social-relational leadership theory is leader-member exchange theory (LMX) (Dinh et al., 2014). LMX theory focuses on dyadic and continuous interactions between two parties or two partners (Graen \& Uhl-Bien, 1991) Brower, Schoorman, and Tan (2000) shortly explain that leaders work with some followers more closely, and in return these particular followers are more likely to trust their leaders, comply with their orders, and work intensively.

Fifth major leadership paradigm is neo charismatic (new leadership) leadership theory (Bass, 1997; Day \& Antonakis, 2012; Dinh et al, 2014). Transactional/transformational leadership is an important subject in this leadership paradigm (Bass, 1997). Transactional leadership is about managing and monitoring followers with a sanction-reward mechanism (Antonakis, Avolio, \& Sivasubramaniam, 2003; Bass, 1997). On the other hand, transformational leaders have proactive personality; they set higher goals and have concerns about collective interests (Antonakis et al., 2003; Horner, 1997). Transformational leadership is more suitable to organizations which require continuous creativity (Shin \& Zhou, 2003). However, all five leadership paradigms are relatively old and some of their implications may no longer be effective at contemporary work environments (Metcalfe \& Metcalfe, 2005). According to Hutchinson and Jackson (2013), these theories did not give enough attention to dark and undesired leadership behaviours. Main claims of these paradigms may not be suitable for young workers (Anderson, Baur, Griffith, \& Buckley, 2017). For instance, it is argued that the concept of authentic leadership may have some pitfalls (Algera \& Wiersma, 2012). Contemporary work conditions may force authentic leaders to dismiss their key values and virtues (Algera \& Wiersma, 2012).

Currently, leadership studies are focusing on sequential events in a particular setting (Broome $\&$ Hughes, 2004). Besides, researchers generally limit the scope of their study into one leadership dimension and they commonly overlook effects of other leadership paradigms on the phenomenon. However, leadership studies have to embrace a more comprehensive approach. Leadership may be more relevant with consciousness, awareness, cognition, thoughts, information processing, and labeling. This comprehensive approach brings us to implicit leadership theory.

\section{Implicit Leadership Theory}


Classic leadership theories deal with leaders' prominent behaviors meanwhile implicit leadership theory tries to explore tacit cognitive framework of leadership (Ling, Chia, \& Fang, 2000). Leadership may be hidden in the cognitive exchange process between leader and followers (Konrad, 2000). Implicit leadership theory highlights cognitive schema and cognitive map (Lim, Othman, Zain, \& Pengiran, 2012). Leader has to fit cognitive expectations of followers (Lim et al., 2012). At the end of the cognitive matching process, the actor will be labeled as a leader (Lim et al., 2012). Ideal cognitive leadership traits, attributes and behaviors about the leader may be originated from socialization (Nonaka, Toyoma, \& Konno, 2000) and past experiences (Epitropaki \& Martin, 2004, 2005; Epitropaki, Martin, Tram-Quon, \& Topakas, 2013). These specific qualities constitute a superset called cognitive leadership prototype (Epitropaki \& Martin, 2004, 2005; Epitropaki et al., 2013; Fraser \& Lord, 1988).Cognitive prototypes provide a simplified image of a leader which highlights prominent leader characteristics for perceiver thereby expediting decision making process and helping the actor to easily recognize the leader (Fraser \&Lord, 1988; Phillips \& Lord, 1986).Junker and Dick (2014) divided prototypes into two categories, namely norm of prototype and valence of prototype. Norm of prototype represents typical-ideal prototypes of leadership and valence of prototype refers to positive or negative perceptions about leadership prototype (Junker \& Dick, 2014). Leader's specific actions, behaviors and attitudes cause followers to consult their prototypes (Cronshaw \& Lord, 1987). At the first cognitive stage, followers quickly label a person as "leader" or "not leader"; then, they regulate their behaviors according to this initial decision (Phillips \& Lord, 1986). When prototype-leader fitness has been ensured, followers do not ask about the leader's authority for a long time (Cronshaw \& Lord, 1987).

Implicit leadership theory is concerned with a labeling process, but the problem is "who will be labeled as a leader?" In this respect, the work of Kenney, Blascovih and Shaver (1994) is of great importance for this paper. According to Kenney et al. (1994), an actor who has different qualities than other group members may also be seen as a leader. This means having distinctive characteristics can make a person a leader in the beholders' eyes. Kenney et al. (1994) emphasized that followers give leadership title to an actor who can make a difference. Making differences may require having different view of life or having different cultural values.

\section{Culture and National Culture}

Culture has become a very complex research area in organization studies because of the interpretation differences among researchers (Leidner \& Kayworth, 2006). Hofstede, Hofstede, and Minkov (2010) and Hofstede, Jonker, and Verwaart (2012) defined culture as software of the mind which determines unwritten rules of the social game. Culture originated from survival styles of societies and it helps to distinguish one community from another (Hofstede, Pedersen, $\&$ Hofstede, 2002). Culture can be conceptualized as shared and constructed collective meaning systems at the group level (Fischer, 2009; Lazear, 1999; Minkov \& Hofstede, 2014). According to Steers, Meyer, and Sunchez-Runde (2008) culture is embedded into social structure of society and its informal rules are followed unconsciously by the majority of society. These informal rules can be learned and passed down with minor changes from generation to generation through time (Steers et al., 2008). 
Hofstede et al. (2010) disintegrate the concept of culture and sort its components from deepest to shallowest as values, rituals, heroes, and symbols. Values rest at the deepest level and they are extremely resistant to change (DeLong\& Fahey, 2000). Trompenaars and Hampden-Turner (1998) divided culture into layers. In the core of the culture there are basic assumptions (implicit); on the middle layer there are norms and values and the outer layer is comprised of artifacts and products (Trompenaars \& Hampden-Turner, 1998). Hofstede et al. (2012) mentioned that culture is unconscious shared systems of values. On the other hand, culture may have a more cognitive and schematic structure. According to DiMaggio (1997), culture has a deep, complex, and implicit structure. Actors use culture as a cognitive schema and this cognitive map mostly manages the decision making process (DiMaggio, 1997). In this way, there may be a relation between cognitive cultural maps and cognitive leadership schemas. In order to relate culture and implicit leadership theory within an alternative perspective, national cultureleadership studies should be examined.

National culture is a very divergent research area. Researchers have tried to build relationship between national culture and other variables. National culture has been related to corporate social responsibility (Peng, Dashdeley, \& Chih, 2014), personality and persuasibility (Chu, 1966), first impression bias reduction (Fang \& Rajkumar, 2013), international business (Leung et al, 2005), fairness in inter-organizational relationships (Lund, Scheer, \& Kozlenkova, 2013), organizational learning culture (Skerlavaj, Su, \& Huang, 2013), management practices (Newman $\&$ Nollen, 1996) and information technology with organizational culture (Leidner \& Kayworth, 2006).Nevertheless, main focus of this study is the relationship between national culture and leadership. The field of management and organization has a rich literature concerning the relationship between national culture and leadership (Bass, 1997; Byrne \& Bradley, 2007; Dorfman et al., 2012; Pasa et al., 2001; Ronen \& Shenkar, 1985; Shaw, 1990; Shim \& Steers, 2012; Smith et al., 1989; Suliman \& Moradkhan, 2013).

This paper evaluates national culture within Hofstede's (1980, 1983) famous cultural framework. Systematic review approach is embraced for answering the main research question. The aim of the systematic review method is to answer a well-defined research question via comprehensive literature review. In systematic review studies, researchers have to explain article selection criteria. In this respect we followed a multi-stage process. First, we collected the most cited papers which focused on implicit leadership theory and national culture. We also reviewed Turkish literature on this subject and added the most cited studies to our collection. We analyzed findings of these papers and separated them into two categories: Category A consists of articles which were found to show an exact match between preferred leadership values and dominant national culture. Category B consists of studies which failed to identify an exact match between preferred leadership values and national culture on each research hypothesis. Then, we focused on Category B and realizing that researchers were not able to provide theoretical assertions for previously mentioned findings, we searched for a theoretical explanation for those results. At the end of our systematic analysis we discovered a particular pattern in these studies. In the following section we make an attempt at establishing a theoretical basis for that pattern.

Hofstede $(1980,1983)$ defined four main cultural dimensions as power distance, uncertainty avoidance, individualism-collectivism, and masculinity-femininity. We will focus on individualism and masculinity dimensions to explore the gaps between implicit leadership theory 
and national culture. In collectivistic cultures society consisting of multilayered, interwoven social groups, every person is obligated to faithfully look after other group members (Hofstede, 1980, 1983; Mooji \& Hofstede, 2002; Oyserman, Coon, \& Kemmelmeier, 2002). On the contrary, individualistic people give emphasis to their private life and their immediate environment (Hofstede, 1980, 1983). Individualistically oriented people live their life without binding local groups and communities (Veiga, Floyd, \& Dechant, 2001). Social context may be more inhibitive for people who live in collectivistic societies. As for feminine culture, it can be a care oriented society and masculine culture can be explained as an achievement oriented society (Hofstede et al., 2002). Masculine people strive for reputable jobs with high salaries and they are used to deal with competitive work environments (Hofstede et al., 2010). Feminine people prefer warm, relation oriented, nurturing work environments (Hofstede et al., 2010).

\section{National Culture and Implicit Leadership Theory}

This study questions whether organizational actors with different cultural values can be accepted as leaders by employees. In terms of national culture, people may accept a person as a leader who is most matched with cultural values. Nevertheless, every employee may not expect a complete cultural fitness from his/her leader. Some people may think that: "the leader should be different than the rest of us". In this respect, the person who has different cultural values may be labeled as a leader. Most of the leadership-culture studies recommend that leader should be coherent with dominant national cultural values (Bass, 1997; Byrne \& Bradley, 2007; Dorfman et al., 2012; Javidan, Dorfman, De Luque, \& House, 2006; Pasa et al., 2001; Ronen \& Shenkar, 1985; Shim \& Steers, 2012; Smith et al., 1989; Suliman \& Moradkhan, 2013; Tabak, Kızıloğlu, \& Türköz, 2013). For example, Pasa et al. (2001) conducted a leadership research on Turkish subjects and they found that most prominent national cultural value is collectivism and it affects paternalistic, considerate, laissez-faire leadership behaviors. Tabak et al. (2013) developed an implicit leadership scale in Turkey and their dimensions (personal morality, skillfulness, sensitiveness, power, and impressiveness) are also compatible with prominent national cultural values of Turkey. Dorfman et al. (2012) asserted that actors who meet the cultural expectations and demands of followers are the most effective leaders. According to Byrne and Bradley (2007) leaders should embrace pluralistic (culturally) leadership styles. Leaders should be aware of cultural differences and try to adapt to the local context (Byrne \& Bradley, 2007). Actor-national culture fitness looks strong up till now. People may want to share common cultural values with their leader and the best representative of national culture may be labeled as a leader in organizations, but some studies found surprising results.

Epitropaki and Martin (2004) developed an implicit leadership scale on British subjects. They specified four leadership prototypes (sensitivity, intelligence, dedication, and dynamism) and two anti-leadership prototypes (tyranny and masculinity);furthermore, sensitivity (helpful, understanding and sincere) was the most prominent factor. The factor of sensitivity may not be fully compatible with the masculine and individualistic national culture of Great Britain (Hofstede, 1980,1983; Hofstede et al., 2010) but people of Great Britain assumed sensitivity as a leadership prototype.

Ling, Chia, and Fang (2000) tried to find out Chinese implicit leadership prototypes. Ling et al. (2000) stated four major prototypes as personal morality, goal efficiency, interpersonal 
competence, and versatility. Most of the factors were matching with Chinese national culture, especially interpersonal competence was highly related with collectivism; however, some aspects of goal efficiency resembled to masculine cultural values like fortitude, decisiveness, competence, and being scientific (Ling et al., 2000).

Holmberg and Akerblom (2006) examined implicit leadership prototypes of Swedish people. They found that team-oriented, participative and autonomous leadership styles are extremely desirable in Sweden (Holmberg \& Akerblom, 2006). Leaders in Sweden should be capable of bringing individuals together and create efficient working groups (Holmberg \& Akerblom, 2006). Despite Sweden's individualistic orientations (Hofstede, 1980, 1983), people of Sweden give great emphasis to team spirit and work groups (Holmberg \& Akerblom, 2006). In this respect, a collectivistically oriented actor may be perceived as a leader on people's minds through his/her relational management skills.

Abdala and Al-Hamoud (2001) explored implicit leadership prototypes in the Arabian Gulf states. Their results are mostly congruent with Arabian national culture, but their interviews with some Kuwaiti people highlighted the importance of boldness and courage on leadership (Abdala \& Al-Hamoud, 2001). Therefore, it would not be impossible to find people who have high femininity to expect more masculine behaviors from the leader.

Bauer (2015) identified Slovak implicit leadership theories within the scope of the Globe research. Benevolent paternalistic team leader factor was found as one of the most important prototypesfor Slovakian people (Bauer, 2015). Slovakia has moderate individualistic and highly masculine national culture (Hofstede, 1980, 1983; Hofstede et al., 2010) but it looks like these people appreciate benevolent and paternalistic behaviors. Bauer (2015) highlighted excessive numbers of "family organizations" (most common form of organization in Slovakia) and the effect of deep "Catholic culture" as the main reasons of these remarkable results.

These arguments look sufficient although there may be another explanation about the interesting results. People may think that leadership title should be given to an actor who can overcome the difficulties originated from dominant national culture. National culture can be thought as the other side of the same coin (Hampden-Turner \& Trompenaars, 2000). The person who can overcome cultural challenges may become a leader on minds.

Brodbeck et al. (2000) examined twenty-two European countries and determined country specific outstanding leadership prototypes. Most of the leadership factors found coherence with national culture, nonetheless there were some interesting results (Brodbeck et al., 2000). For instance, Russian people put humane oriented leadership into the negative (low) leadership category (Brodbeck et al., 2000). A collectivist and feminine country should have evaluated humane oriented leadership more positively. There should be a theoretical explanation of these views. Employees or followers may want to see something different from their leaders. Kono, Ehrhart, Ehrhart, and Schultze (2012) compared implicit leadership perceptions and prototypes of people from Japan and U.S. They came up with the same interesting and opposing results (Kono et al., 2012). Compared with the Japanese participants, people from U.S. scored higher on administratively competent, collaborative team orientation, and collaborative team integrator dimensions. In other words, the interviewees from U.S. rated all of the team oriented leadership dimensions higher than their Japanese counterparts (Kono et al., 2012). Furthermore, participants 
from U.S. found the autocratic leadership more favorable in comparison to Japanese participants (Kono et al., 2012).

This paper aims at building a theoretical framework for the opposite results of implicit leadership researches. People may be impressed by the effective unusual behaviors and attitudes. Hofstede \& McCrae (2004) underlined that a particular culture does not cover all the people living in that society. In every society, some people may have distinct cultural values compared to the majority. For example, a person may encounter highly individualistically oriented people in Turkey. Highly collectivistic people exist in USA and all other individualistic societies. These unusual actors may solve major problems of organizations with their exceptional skills. Culture implicitly manages knowledge creation, sharing, and use at organizational level (DeLong \& Fahey, 2000). Organizational actors who have different cultural values may be more capable of disseminating and managing knowledge in organizations. At the end of this problem solving and knowledge managing process, people may convert this person into a leader in their minds. In this respect, contemporary leadership studies are neglecting the notion of early leadership studies which put forward the idea of leaders who should be different than others (Day et al, 2014; Dinh et al., 2014; House \& Aditya, 1997; Judge, Piccolo, \& Kosalka, 2009; Mortensen et al., 2014). Meeting the demands of cultural expectations or becoming a good representative of national culture may not be enough to be labeled as a leader.

Proposition 1: Organizational actors who have different cultural values than the majority of employees are more likely to be labeled as leaders by those employees.

This cognitive labeling and evaluating process will probably not proceed identically within individualistic and collectivistic societies. Shaw (1990) mentioned that leadership prototypes of highly collectivistic cultures will be more similar to each other compared to highly individualistic societies. Shortly, collectivistic cultures are more close to discrepancies and diversities among organization members in their environment (Shaw, 1990). Collectivistic people may be emotionally attached to their work groups and they may even feel obligated to the other group members (Swaidan \& Hayes, 2005). Collectivistic people may not give credit to importance of diversity and variety very quickly. The information processing and accepting variety probably will take more time for them in comparison with individualistic people.

Proposition $_{2}$ : Organizational actors who have different cultural values than the majority of employees are more likely to be labeled as leaders by the individualistically oriented employees.

In order to achieve complicated, intensive, and challenging tasks, organizations need team work and work groups (Driskel, Salas, \& Hughes, 2000). Teamwork concentrates and integrates dispersed information, regulates this information, and accelerates business process (Salas, Cooke, \& Rosen, 2008). Organizations require an actor who is capable of bringing individuals together and organize them for accomplishing specific tasks. This kind of leadership is called as team oriented leadership. Team oriented leadership is one of the implicit leadership dimensions which is determined in the Globe study (Dorfman et al., 2012). Team leadership is mostly concerned with managing social issues, guiding social affairs, and looking after everyone's 
interest in the social group (Burke et al., 2006). Organizational actors from collectivistic countries may be more skillful when overcoming social problems. Actors who have high collectivistic orientation feel more dependent to their working groups and these people have high tendency to work collaboratively (Wagner, 1995). Individualistic people give priority to their own desires instead of the collective interests (Wagner, 1995). Highly individualistic employees may feel pressured or distressed when the team work is a necessity for completing certain tasks. Non-cooperative work teams may cause numerous problems in organizations (Driskel et al., 2000). Culture can easily be seen as a scapegoat in this kind of situations (Leidner \& Kayworth, 2006). On the other hand, actors with high collective orientation canassure effective team performance (Driskel et al., 2000). In this respect, highly individualistic employees may assume collectivistic orientation as a leadership prototype.

Proposition: People from highly individualistic societies are prone to label team oriented leadership dimension as their outstanding leadership prototype.

Humane oriented leadership is also an important implicit leadership dimension (Bauer, 2015; Brodbeck et al., 2000; Dorfman et al., 2012). Humane oriented leaders prefer to be kind, assistive, empathetic, thoughtful, compassionate to their followers, and their humanistic behaviors are appreciated by employees (Dorfman et al., 2012; Javidan et al., 2006). The general aspects of masculine culture like speed, rivalry, money, competition, and ambition (Hofstede, 1980,1983) may cause adverse effects. People may require more altruistically oriented leadership in that kind of work environments. In a highly masculine society people may be impressed by a humane oriented leadership.

Proposition $_{4}$ People from highly masculine societies are prone to label humane oriented leadership dimension as their outstanding leadership prototype.

\section{Discussion and Conclusion}

National culture and implicit leadership seem to be two separate concepts which can hardly be related to each other. This paper provides theoretical basis for the unexpected and opposite results of national culture-leadership studies. Exceptional individuals who have cultural values opposite to the majority may be quite useful for organizations. Unusual actors always have a chance to make highly positive impressions. If culturally differentiated actors can use their competencies effectively, then they may overcome cultural constraints (Hofstede, 1993). Different cultural values may bring along different perspectives. Having a different point of view may reveal hidden solutions otherwise unseen to organizational actors. These remarkable actors may be skillful in problem solving as well as organizing other people. Team work versus individual work is one of the major dilemmas of the organizational behavior literature. Some people are much more productive when they work alone, other people may prefer working with a team or a group. National culture may have an effect on these preferences. Highly individualistic people may prefer working alone and being responsible only for their actions. These people may not have adequate competencies to accomplish group tasks. In the same manner, highly collectivistic employees may have difficulties focusing on individual missions. 
In situations where employees may have organizing problems, a culturally differentiated actor can guide the organization to a better administration. At the end of this guiding process, culturally differentiated actor may be seen as a leader.

Cultural diversity and discrepancy are very important issues in the leadership process. Some cultures are more eager to accept diversity. People's tolerance to diversity may differ among different cultures. People from individualistic cultures are more willing to accept diversity (Shaw, 1990). Collectivistically oriented people may prefer to give more credit to resemblances and similarities. In this respect, individualistically oriented employees are more likely to recognize the importance of distinctness in organizations. Organizational actors who have different cultural values can turn into leaders more quickly in individualistic societies.

Every national culture in the world has positive and negative aspects. Organizations may need a leader who can counterbalance cultural gaps. In individualistic societies, organizations may require an actor who has the capacity of unifying employees and converting them into work teams. Organizations may require team oriented leaders for achieving group tasks in highly individualistic societies. In such societies, organizational actors may have to put extra effort to build coherent work teams. Convincing people about the benefits of team work may be much more difficult. Highly individualistic people may evaluate the team oriented leadership dimension as outstanding leadership prototype: Because the team oriented leadership may be the most needed leadership style in highly individualistic settings. In a similar manner, people in highly masculine societies may be in need of humane oriented leadership. Humane oriented leaders can balance masculine tendencies in organizations. They can compensate for the emotional needs of employees. That kind of organizational actors can be assumed as leaders.

Consequently, the present study explored theoretical reasons of unexpected and opposite results of national culture-implicit leadership theory researches. The importance of distinctness has been highlighted throughout the study. Organizations always need actors who have different points of view. Organizational actors who have different cultural values may enrich the organization's knowledge capital and become a leader on beholders' eyes.

Despite its theoretical contributions, this paper has several limitations. Our first limitation is time constraint. This study is prepared in a limited time interval. The conditions and circumstances in which unusual actors stand out as leaders can be explained more deeply in a broader time interval. The sociology of culture may be used for more extensive explanations. Second, the propositions of this study were not tested. In order to obtain more generalizable results, future researchers may convert our propositions to hypotheses and test them on a proper sample.

\section{References}

Abdalla, I. A., \& Al-Homoud, M. A. (2001). Exploring the implicit leadership theory in the Arabian Gulf states. Applied Psychology: An International Review, 50(4), 506-531.

Algera, P. M., \& Lips-Wiersma, M. L. (2012). Radical authentic leadership: Co-creating the conditions under which all members of the organization can be authentic. The Leadership Quarterly, 23(1), 118-131.

Anderson, H. J., Baur, J. E., Griffith, J. A., \& Buckley, M. R. (2017). What works for you may not work for (Gen) me: Limitations of present leadership theories for the new generation. The Leadership Quarterly, 28(1), 245-260.

Antonakis, J., Avolio, B., \& Sivasubramaniam, N. (2003). Context and leadership: An examination of the nine-factor full-range leadership theory using the multifactor leadership questionnaire. The Leadership Quarterly, 14, 261-295. 
Bass, B. M. (1997). Does the transactional-transformational leadership paradigm transcend organizational and national boundaires? American Psychologist, 52(2), 130-139.

Bauer, D. (2015). Successful leadership behaviours in Slovak organizations' environment an introduction to Slovak implicit leadership theories based on GLOBE study findings. Journal for East European Management Studies, 20(1),9-35.

Blank, W., Weitzel, J. R., \& Green, S. G. (1990). A test of situational leadership theory. Personal Psychology, 43(3), $579-597$.

Bowers, D. G., \& Seashore, S. E. (1966). Predicting organizational effectiveness with a four factor theory of leadership. Administrative Science Quarterly, 11(2), 238-263.

Broome, G. H., \& Hughes, R. L. (2004). Leadership development: Past, present and future. Human Resource Planning, 27(1), 24-32.

Brodbeck, F. C., Frese, M., Akerblom, S., Audia, G., Bakacsi, G., Bendova, H., . . Wunderer, R. (2000). Cultural variation of leadership prototypes across 22 European countries. Journal of Occupational \& Organizational Psychology, 73(1), 1-29.

Brower, H. H., Schoorman, F. D., \& Tan, H. H. (2000). A model of relation leadership: The integration of trust and leadermember exchange. Leadership Quarterly, 11(2), 227-250.

Burke, S. C., Stagl, K. C., Klein, C., Goodwin, G. F., Salas, E., \& Halpin, S. M. (2006). What type of leadership behaviors are functional in teams? A meta-analysis. The Leadership Quarterly, 17, 288-307.

Byrne, G. J., \& Bradley, F. (2007). Culture's influence on leadership efficiency: How personal and national cultures affect leadership style. Journal of Business Research, 60, 168-175.

Campbell, R. N. (1968). Review of the book: A theory of leadership effectiveness by Fred E. Fiedler. Administrative Science Quarterly, 13(2), 344-348.

Chu, G. C. (1966). Culture, personality and persuasibility. Sociometry, 29(2), 169-174.

Cronshaw, S. F., \& Lord, G. R. (1987). Effects of categorization, attribution and encoding processes on leadership perceptions. Journal of Applied Psychology, 72(1), 97-106.

Day, D., \& Antonakis, J. (2012). Leadership: Past, Present, and Future. In D. V. Day, \& J. Antonakis (Eds.), The Nature of Leadership (pp. 3-25). California: SAGE Publishing.

Day, D. V., Fleenor, J. W., Atwater, L. E., Sturm, R. E., \& McKee, R. A. (2014). Advances in leader and leadership development: A review of 25 years of research and theory. The Leadership Quarterly, 25(1),63-82.

DeLong, D. W., \& Fahey, L. (2000). Diagnosing cultural barriers to knowledge management. Academy of Management Executive, 14(4), 113-127.

Derue, S.D., Nahrgang, J. D., Wellman, N., \& Humphrey, S. E. (2011). Trait and behavioral theories of leadership: An integration and meta-analytic test of their relative validity. Personnel Psychology, 64(1),7-52.

DiMaggio, P. (1997). Culture and Cognition. Annual Review of Sociology, 23(1), 263-287.

Dinh, J. E., Lord, R. G., Gardner, W. L., Meuser, J. D., Liden, R. C., \& Hu, J. (2014). Leadership theory and research in the new millennium: Current theoretical trends and changing perspectives. The Leadership Quarterly, 25(1), 36-62.

Dorfman, P., Javidan, M., Hanges, P., Dastmalchian, A., \& House, R. (2012). Globe: A twenty-year journey into the intriguing world of culture and leadership. Journal of World Business, 47(4), 504-518.

Driskel, J. E., Salas, E., \& Hughes, S. (2010). Collective orientation and team performance: Development of an individual differences measure. The Journal of Human Factors \& Ergonomics Society, 52, 316-328.

Epitropaki, O., \& Martin, R. (2004). Implicit leadership theories in applied settings: Factor structure, generalizability, and stability over time. Journal of Applied Psychology, 89(2), 293-310.

Epitropaki, O., \& Martin, R. (2005). From ideal to real: A longitudinal study of the role of implicit leadership theories on leadermember exchanges and employee outcomes. Journal of Applied Psychology, 90(4), 659-676.

Epitropaki, O., Martin, R., Tram-Quon, S. \& Topakas, A. (2013). Implicit leadership and followership theories "in the wild": Taking stock of information-processing approaches to leadership and followership in organizational settings. The Leadership Quarterly, 24, 858-881.

Fang, X., \&Rajkumar, T. M. (2013). The role of national culture and multimedia on first impression bias reduction: an experimental study in US and China. IEEE Transactions on Professional Communication, 56(4), 354-371.

Fischer, R. (2009). Where is culture in cross cultural research? An outline of a multilevel research process for measuring culture as a shared meaning system. Cross Cultural Management, 9(1), 25-49.

Fraser, S. L. \& Lord, R. G. (1988). Stimulus prototypicality and general leadership impressions: Their role in leadership and behavioral ratings. The Journal of Psychology, 122(3), 291-303.

Graeff, C. L. (1983). The situational leadership theory: A critical review. Academy of Management Review, 8(2),285-291. 
Graen, G. B., \& Uhl-Bien, M. (1991). The transformation of professionals into self-managing and partially self-designing contributors: Toward a theory of leadership-making. Journal of Management Systems, 3(3), 25-39.

Hampden-Turner, C. M., \& Trompenaars, F. (2000). Building cross cultural competence: How to create wealth from conflicting values. New Heaven, CT: Yale University Press.

Hill, W. (1969). The validation and extension of Fiedler's theory of leadership effectiveness. The Academy of Management Journal, 12(1), 33-47.

Hofstede, G. (1980). Motivation, leadership, and organization: Do American theories apply abroad. Organizational Dynamics, $9(1), 42-63$.

Hofstede, G. (1983). The cultural relativity of organizational practices and theories. Journal of International Business Studies, 14(2), 75-89.

Hofstede, G. (1993). Cultural constraints in management theories. Academy of Management Executive, 7(1), 81-94.

Hofstede, G. H., Hofstede, G. J., \& Minkov, M. (2010). Cultures and organizations: Software of the mind. New York, NY: The McGraw Hill Companies.

Hofstede, G, J., Jonker, C. M., \& Verwaart, T. (2012). Cultural differentiation of negotiating agents. Group Decision \& Negotiation, 21(1),79-98.

Hofstede, G., \& McCrae, (2004). Personality and culture revisited: linking traits and dimensions of culture. Cross-Cultural Research, 38(1), 52-88.

Hofstede, G. J., Pedersen, P. B., \& Hofstede, G. (2002). Exploring culture: Exercises, stories and synthetic cultures. Boston: Intercultural Press.

Holmberg, I., \& Akerblom, S. (2006). Modelling leadership: Implicit leadership theories in Sweden. Scandinavian Journal of Management, 22,307-329.

Horner, M. (1997). Leadership theory: Past, present and future. Team Performance Management, 3(4), $270-287$.

House, R. J. (1971). A path goal theory of leader effectiveness. Administrative Science Quarterly, 16(3), 321-339.

House, R. J., \& Aditya, R. N. (1997). The social scientific study of leadership: Quo vadis? Journal of Management, 23(3), 409473.

Hutchinson, M., \& Jackson, D. (2013). Transformational leadership in nursing: Towards a more critical interpretation. Nursing Inquiry, 20(1), 11-22.

Javidan, M., Bullough, A. \& Dibble, R. (2016). Mind the gap: Gender differences in global leadership self-efficacies. The Academy of Management Perspectives, 30(1),59-73.

Javidan, M., Dorfman, P. W., De Luque, M. S., \& House, R. J. (2006). In the eye of the beholder: Cross cultural lessons in leadership from project GLOBE. Academy of Management Perspectives, 20(1), 67-90.

Judge, T. A., Piccolo, R. F., \& Kosalka, T. (2009). The bright and dark sides of leader traits: A review and theoretical extension of the leader trait paradigm. The Leadership Quarterly, 20, 855-875.

Junker, N. M., \& van Dick, R. (2014). Implicit theories in organizational settings: A systematic review and research agenda of implicit leadership and followership theories. The Leadership Quarterly, 25(6), 1154-1173.

Justis, R. T. (1975). Leadership effectiveness: A contingency approach. Academy of Management Journal, 18(1),160-167.

Kenney, R. A., Blascovich, J., \& Shaver, P. (1994). Implicit leadership theories: Prototypes for new leaders. Basic \& Applied Social Psychology, 15(4), 409-437.

Kono, T., Ehrhart, K. H., Ehrhart, M. G., \& Schultze, T. (2012). Implicit leadership theories in Japan and the US. Asia Pacific Journal of Human Resources, 50, 367-387.

Konrad, E. (2000). Implicit leadership theories in Eastern and Western Europe. Social Science Information, 39(2),335-347.

Kotter, J. P. (2001). What leaders really do. Harward Business Review, 79(11),85-96.

Lazear, E. P. (1999). Culture and language. Journal of Political Economy, 107(6), 95-126.

Leidner, D. E., \& Kayworth, T. (2006). A review of culture in information systems research: Toward a theory of information technology culture conflict. MIS Quarterly, 30(2), 357-399.

Leung, K., Bhagat, R. S., Buchan, N. R., Erez, M., \& Gibson, C. B. (2005). Culture and international business: Recent advances and their implications for future research. Journal of International Business Studies, 36(4), 357-378.

Lim, S., Othman, R., Zain, A. Y., \& Pengiran, D. S. R. (2012). Implicit leadership theories of Bruneians. Journal of Asia-Pacific Business, 13(4), 302-319.

Ling, W., Chia, R., \& Fang, L. (2000). Chinese implicit leadership theory. The Journal of Social Psychology, 140(6), 729-739. 
Lund, D. J., Scheer, L. K., \& Kozlenkova, I. V. (2013). Culture's impact on the importance of fairness in inter-organizational relationships. Journal of International Marketing, 21(4), 21-43.

Mathews, J. (2016). Toward a conceptual model of global leadership. IUP Journal of Organizational Behavior, 15(2),38-55.

Metcalfe, B. A., \& Metcalfe, J. A. (2005). Leadership: Time for new a new direction? Leadership, 1(1), 51-71.

Minkov, M., \& Hofstede, G. (2014). Clustering of 316 European regions on measures of values: do Europe's countries have national cultures? Cross-Cultural Research, 48(2), 144-176.

Mooij, M. D., \& Hofstede, G. (2002). Convergence and divergence in consumer behavior: implications for international retailing. Journal of Retailing, 78, 61-69.

Mortensen, J., Lichty, L., Foster-Fishman, P., Harfst, S., Hockin, S., Warsinke, K., \& Abdullah, K. (2014). Leadership through a youth lens: Understanding of youth conceptualization of leadership. Journal of Community Psychology, 42(4), 447-462.

Newman, K, L., \& Nollen, S. D. (1996). Culture and congruence: The fit between management practices and national culture. Journal of International Business Studies, 27(4), 753-779.

Nonaka, I., Toyoma, R., \& Konno, N. (2000). SECI, ba and leadership: A unified model of dynamic knowledge creation. Long Range Planning, 33, 5-34.

Northouse, P. G. (2010). Leadership: Theory and practice. California, Thousand Oaks: SAGE Publications.

Oyserman, D., Coon, H. M., \& Kemmelmeier, M. (2002). Rethinking individualism and collectivism: Evaluation of theoretical assumptions and meta-analyses. Psychological Bulletin, 128(1), 3-72.

Pasa, S. F., Kabasakal, H., \& Bodur, M. (2001). Society, organizations and Leadership in Turkey. Applied Psychology: An International Review, 50(4), 559-589.

Peng, Y. S., Dashdeleg, A. U., \& Chih, H. L. (2014). National culture and firm's CSR engagement: A cross-nation study. Journal of Marketing \& Management, 5(1), 38-49.

Phillips, J. S., \& Lord, R. G. (1986). Notes on the practical and theoretical consequences of implicit leadership theories for the future of leadership measurement. Journal of Management, 12(1),31-41.

Ronen, S., \& Shenkar, O. (1985). Clustering countries on attitudinal dimensions: A review and synthesis. Academy of Management Review, 10(3), 435-454.

Salas, E., Cooke, N. J. \& Rosen, M. A. (2008). On teams, team work, and team performance: Discoveries and developments. Human Factors, 50(3),540-547.

Shaw, J. B. (1990). A cognitive categorization model for the study of intercultural management. The Academy of Management Review, 15(4), 626-645.

Shim, W. S., \& Steers, R. M. (2012). Symmetric and asymmetric leadership cultures: A comparative study of leadership and organizational culture at Hyundai and Toyota. Journal of World Business, 47, 581-591.

Shin, S. J., \& Zhou, J. (2003). Transformational leadership, conservation, and creativity: Evidence from Korea. The Academy of Management Journal, 46(6),703-714.

Skerlavaj, M., Su, C., \& Huang, M. (2013). The moderating effects of national culture on the development of organisational learning culture: A multilevel study across seven countries. Journal for East European Management Studies, 18(1), 97-134.

Smircich, L., \& Morgan, G. (1982). Leadership: The management of meaning. The Journal of Applied Behavioral Science, 18(3), $257-273$.

Smith, P. B., Misumi, J., Tayeb, M., Peterson, M., \& Bond, M. (1989). On the generality of leadership style measures across cultures. Journal of Occupational Psychology, 62, 97-109.

Steers, R. M., Meyer, A. D., \& Sanchez-Runde, C. J. (2008). National culture and the adoption of new technologies. Journal of World Business, 43, 255-260.

Suliman, A., \&Moradkhan, E. (2013). Leadership and national culture in the UAE. Global Conference on Business \& Finance Proceedings, 8(2), 408-423.

Summerfield, M. R. (2014). Leadership: A simple definition. American Journal of Health-System Pharmacy, 71(3), $251-253$.

Swaidan, Z., \& Hayes, L. A. (2005). Hofstede theory and cross cultural ethics conceptualization, review, and research agenda. The Journal of American Academy of Business, 6(2), 10-15.

Tabak, A., Kızıloğlu, A., \&Türköz, T. (2013). Örtülü liderlik ölçeği geliştirme çalışması. ODTÜ Gelişme Dergisi, 40, 97-138.

Trompenaars, F., \& Hampden-Turner, C. (1998). Riding the waves of culture: Understanding cultural diversity in global business. London: Nicholas Brealey Publishing. 
Vecchio, R. P. (1987). Situational leadership theory: an examination of a prescriptive theory. Journal of Applied Psychology, $72(3), 444-451$.

Veiga, J. F., Floyd, S., \& Dechant, K. (2001). Towards modelling the effects of national culture on IT implementation and acceptance. Journal of Information Technology, 16, 145-158

Wagner, J. A. (1995). Studies of individualism-collectivism: Effects on cooperation in groups. Academy of Management Journal, 38(1), 152-172. 